\title{
Correction to: Deleterious effects of dialysis emergency start, insights from the French REIN registry
}

Alain Michel ${ }^{1 *}$, Adelaide Pladys ${ }^{2,3}$, Sahar Bayat ${ }^{2,4}$, Cécile Couchoud ${ }^{5}$, Thierry Hannedouche ${ }^{6}$ and Cécile Vigneau ${ }^{1,7,8}$

\section{Correction}

Following publication of the original article [1], the authors reported that all of the authors' names were processed incorrectly so that their given and family names were interchanged. In this Correction the correct author names are shown. The original publication of this article has been corrected.

The correct names are: Alain Michel, Adelaide Pladys, Sahar Bayat, Cécile Couchoud, Thierry Hannedouche and Cécile Vigneau.

\section{Author details}

${ }^{1} \mathrm{CHU}$ Pontchaillou, Service de néphrologie, 2 rue H Le Guilloux, 35033 Rennes, France. 'EHESP, Département d'Epidémiologie et de Biostatistiques, Rennes, France. ${ }^{3}$ Université Rennes 1, UMR CNRS, 6290 Rennes, France. ${ }^{4} E A$ MOS EHESP, Rennes, France. ${ }^{5}$ Registre REIN, Agence de la biomédecine, La Plaine Saint Denis, France. ${ }^{6}$ Faculté de médecine de Strasbourg, Hôpitaux universitaires de Strasbourg, 1 place de l'Hôpital, 67091 Strasbourg, France. ${ }^{7}$ Université de Rennes 1, 2 av prof L Bernard, 35000 Rennes, France. ${ }^{8}$ Inserm (Institut national de la santé et de la recherche médicale), IRSET, U1085, SFR Biosit, 9 Avenue du Professeur Léon Bernard, 35000 Rennes, France.

Received: 1 October 2018 Accepted: 1 October 2018

Published online: 15 October 2018

\section{Reference}

1. Michel A, et al. Deleterious effects of dialysis emergency start, insights from the French REIN registry. BMC Nephrol. 2018;19:233 https://doi.org/10.1186/ s12882-018-1036-9.

\footnotetext{
* Correspondence: alain.michel@chu-rennes.fr

${ }^{1} \mathrm{CHU}$ Pontchaillou, Service de néphrologie, 2 rue H Le Guilloux, 35033

Rennes, France

Full list of author information is available at the end of the article
}

(c) The Author(s). 2018 Open Access This article is distributed under the terms of the Creative Commons Attribution 4.0 International License (http://creativecommons.org/licenses/by/4.0/), which permits unrestricted use, distribution, and reproduction in any medium, provided you give appropriate credit to the original author(s) and the source, provide a link to the Creative Commons license, and indicate if changes were made. The Creative Commons Public Domain Dedication waiver (http://creativecommons.org/publicdomain/zero/1.0/) applies to the data made available in this article, unless otherwise stated. 